\title{
The application of different techniques to determine activated sludge kinetic parameters in a food industry wastewater
}

\author{
Edgardo Contreras ${ }^{1}$, Nora Bertola ${ }^{1,2}$ and Noemí Zaritzky ${ }^{1,2 *}$ \\ ${ }^{1}$ Centro de Investigación y Desarrollo en Criotecnología de Alimentos (CIDCA). CONICET - Fac. Ciencias Exactas \\ ${ }^{2}$ Fac. de Ingeniería. Universidad Nacional de La Plata. 47 y 116 (1900) La Plata, Argentina
}

\begin{abstract}
In the present work, a continuous-feed system under steady state conditions (classical method) and a respirometric technique based on oxygen consumption measurements, were used to compare microbial parameters using a wastewater model system of a potato processing plant. The effects of the operating conditions in the continuous aerobic reactor on microbial growth and flora composition were also analysed.

Continuous-feed experiments allowed for the calculation of the following biodegradation parameters: maximum substrate consumption specific rate $\left(\mathrm{q}_{\mathrm{Smax}}\right)=0.19 \mathrm{mgCOD}(\mathrm{mgVSS})^{-1} \cdot \mathrm{h}^{-1}$, saturation constant $(\mathrm{Ks})=8.3 \mathrm{mgCOD} \cdot \ell^{-1}$, biomass yield $\left(\mathrm{Y}_{\mathrm{X} / \mathrm{S}}\right)=$ $0.61 \mathrm{mgVSS}(\mathrm{mgCOD})^{-1}$, biomass decay constant $(\mathrm{kd})=0.04 \cdot \mathrm{h}^{-1}$ and maximum oxygen consumption specific rate $\left(\mathrm{q}_{\mathrm{O} 2 \max }\right)=0.03$ $\operatorname{mgCOD}(\mathrm{mgVSS})^{-1} \cdot \mathrm{h}^{-1}$.

The respirometric technique als allowed for the calculation of kinetic parameters. However, these parameters depended on dilution rate (D) and/or on dissolved oxygen concentration (DO). Values of $\mathrm{q}_{\mathrm{O} 2 \max }$ and Ks increased with $\mathrm{D} ; \mathrm{q}_{\mathrm{O} 2 \max }$ ranged between 0.05 and $0.13 \mathrm{mgO}_{2}(\mathrm{mgVSS})^{-1} \cdot \mathrm{h}^{-1}$ and Ks between 2 and $26 \mathrm{mgCOD} \cdot \ell^{-1}$ for D values varying between 0.01 and $0.15 \cdot \mathrm{h}^{-1}$.

Microscope observations showed that sludge composition was a function of dilution rate. Low $\mathrm{D}$ values (low soluble organic matter ( $\mathrm{Ss}$ ) and high DO concentrations) yielded sludges mainly formed by floc-forming bacteria; high D values (high Ss and low DO concentrations) yielded sludges mainly formed by filamentous micro-organisms.

Since the low substrate/biomass ratios used in the respirometric method limit the growth of micro-organisms maintaining the initial physiological state of the original biomass, the observed differences in the respirometric parameters reflected the actual microbial composition.
\end{abstract}

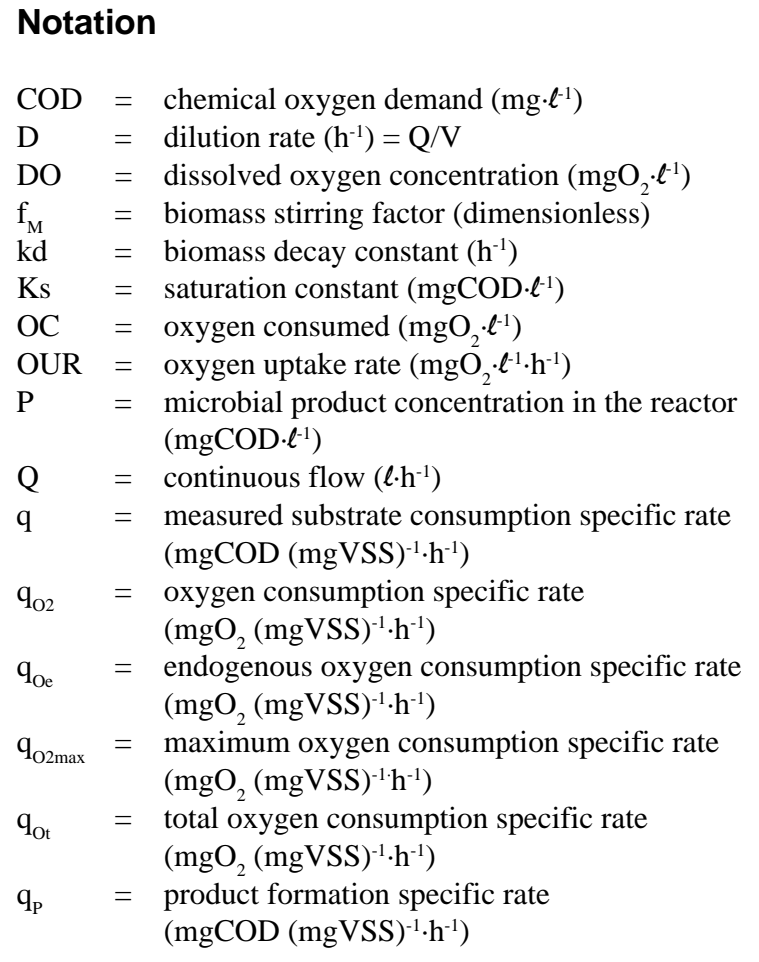

* To whom all correspondence should be addressed.

푱/fax 54-221-4254853/4249287/4890741

e-mail: zaritzky@volta.ing.unlp.edu.ar / nbertola@volta.ing.unlp.edu.ar

Received 14 June 2000; accepted in revised form 17 January 2001.

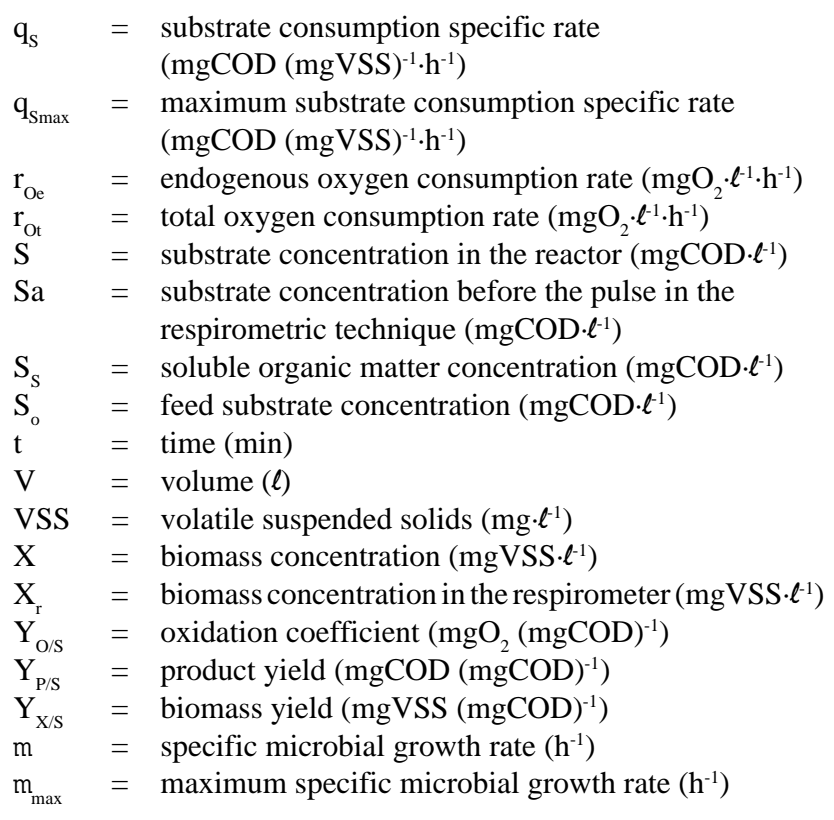

\section{Introduction}

Among aerobic biological wastewater treatments, activated sludge systems play an important role. Waste is discharged into large aeration basins in which atmospheric oxygen is diffused by releasing compressed air into the waste or by mechanical surface aerators. Both substrate consumption kinetics and floc-forming capacity of the sludge determine process efficiency. The operation mode of the aeration unit affects the physical properties of the flocs and may 
limit the clarification capacity of the secondary settling tank.

The wastewater of a potato-processing plant includes constituents of the potato that are readily water soluble and appear as dissolved solids, such as solubilised starch, proteins, amino acids, organic acids, and sugars. The organic portion of the waste stream can only be removed by biological treatments (Pailthorp et al., 1975).

Operational problems are known to occur in the activated sludge treatment of potato wastewater, primarily connected with sludge settling in secondary clarifiers. The high carbohydrate waste may be prone to filamentous bacterial growth if the aeration basin environmental conditions are not maintained in the proper ranges (Pailthorp et al., 1975; Sezgin et al., 1978; Wanner, 1994). Considering that biological degradation is the most widely used method to reduce organic loading of wastewater, knowledge of microbial kinetics becomes essential for biological treatment design and to establish the operating conditions that produce sludges with adequate settling characteristics.

Many techniques have been proposed for measuring the kinetics of biodegradation, continuous-feed systems (classical technique) being the most used and accepted one (Pirt, 1975). In these cases, the reactor is fed varying dilution rates. Once the system reaches steady state, the corresponding substrate concentration and biomass are determined. In general, reaching steady state takes considerable time (Williamson and McCarty, 1975) which is its main disadvantage.

Several authors have used respirometric techniques for the determination of microbial kinetic parameters (Cech et al., 1984; Dang et al., 1989; Aichinger et al., 1992; Drtil et al., 1993; Orhon et al., 1995; Ellis et al., 1996; Ubisi et al., 1997), biochemical oxygen demand (Köhne, 1985; Ros, 1993), toxicity of wastewaters (King and Dutka, 1986; Vanrolleghem et al., 1994; Kong et al., 1996) and as an on-line biosensor in wastewater treatment plants (Holmberg et al., 1989; Sollfrank and Gujer, 1990; Vanrolleghem et al., 1994). This method is based on the determination of OUR as related to the biodegradation of a known substrate amount. Although respirometric technique constitutes a rapid and easy method, there are many complicating factors associated with the measurement of kinetic and stoichiometric parameters such as the feed pattern (Chudoba et al., 1985; Beccari et al., 1998), substrate storage (Chudoba et al., 1992; Dircks et al., 1999; Majone et al., 1999) or anoxic-aerobic conditions (Liu et al., 1998; Musvoto et al., 1999; Casey et al., 1999) which restrict or limit its applicability.

The objectives of the present work were to:

- determine and compare microbial kinetic parameters in a continuously stirred activated sludge reactor treating potato processing wastewater by using classical and respirometric techniques; and

- analyse the effect of dilution rate on the microflora modifications and on the respirometric parameters.

\section{Mathematical modelling}

\section{Continuous-feed method (classical technique)}

Considering a continuously stirred-tank reactor, mass balances for substrate, biomass and product are given as follows:

Mass balance of substrate (completely stirred system)

$$
\frac{d S}{d t}=D\left(S_{0}-S\right)-q s X
$$

where:

$\mathrm{S}=$ non-degraded substrate concentration in the reactor $\left(\mathrm{mgCOD} \cdot \ell^{-1}\right)$,

So $=$ feeding substrate concentration $\left(\operatorname{mgCOD} \cdot \ell^{-1}\right)$,

$\mathrm{q}_{\mathrm{S}}=$ substrate consumption specific rate (mgCOD $\left.(\mathrm{mgVSS})^{-1} \cdot \mathrm{h}^{-1}\right)$

$\mathrm{D}=$ dilution rate $\left(\mathrm{h}^{-1}\right)$,

$\mathrm{X}=$ biomass concentration $\left(\mathrm{mgVSS} \cdot \ell^{-1}\right)$.

Under steady state, the substrate mass balance results are:

$$
q_{s}=\frac{D\left(S_{0}-S\right)}{X}
$$

\section{Mass balance of biomass}

$$
\frac{d X}{d t}=\mu X-k d X-D f_{M} X
$$

where:

$\mathrm{m}=$ specific microbial growth rate $\left(\mathrm{h}^{-1}\right)$,

$\mathrm{kd}=$ biomass decay constant $\left(\mathrm{h}^{-1}\right)$,

$\mathrm{f}_{\mathrm{M}}=$ biomass stirring factor, defined as the ratio between the biomass concentration in the discharge stream and the biomass concentration in the reactor.

This factor was added to take into account that some microorganisms may attach to the reactor walls. According to Pirt (1975), in continuous-flow cultures of long duration, there may be biofilm formation which varies from a light film of biomass to a massive accretion of it on the vessel surface. The biomass in the reactor is given by the sum of the biofilm formation and the biomass of the discharge stream. Thus, the biomass discharge concentration is always lower than the concentration in the reactor. The laboratory reactor has an $\mathrm{f}_{\mathrm{M}}$ of 0.56 determined in a previous paper (Bertola et al., 1999).

Once steady state is reached Eq. (3) becomes:

$$
\mu=f_{M} D+k d
$$

\section{Balance of product}

$$
\frac{d P}{d t}=q_{P} X-D P
$$

where:

$$
\begin{aligned}
\mathrm{P}= & \begin{array}{l}
\text { microbial product concentration in the reactor } \\
\left(\operatorname{mgCOD} \cdot \ell^{-1}\right)
\end{array} \\
\mathrm{q}_{\mathrm{P}}= & \begin{array}{l}
\text { product formation specific rate } \\
\left(\operatorname{mgCOD}(\mathrm{mgVSS})^{-1} \cdot \mathrm{h}^{-1}\right)
\end{array}
\end{aligned}
$$

Under steady state Eq. (5) leads to:

$$
q_{P}=\frac{D P}{X}
$$

In a previous paper, Bertola et al. (1999) reported the formation of soluble compounds (microbial products) due to microbial growth. Additionally, no inert compounds were found in the wastewater model system. Therefore, the measured $\mathrm{S}_{\mathrm{S}}$ had two contributions: $\mathrm{S}$ and $\mathrm{P}:\left(\mathrm{S}_{\mathrm{S}}=\mathrm{S}+\mathrm{P}\right)$. Considering the product yield $\left(\mathrm{Y}_{\mathrm{P} / \mathrm{S}}\right)$ as:

$$
Y_{P / S}=\frac{q_{P}}{q_{S}}=\frac{P}{\left(S_{0}-S\right)}
$$

the non-degraded substrate concentration in the outlet stream $(\mathrm{S})$ is 
given by:

$$
S=\frac{S_{S}-Y_{P / S} S_{0}}{1-Y_{P / S}}
$$

Besides, biomass yield $\left(\mathrm{Y}_{\mathrm{X} / \mathrm{S}}\right)$ is defined as:

$$
Y \times / s=\frac{\mu}{q_{s}}
$$

The measured substrate consumption specific rate (q) differs from the substrate consumption specific rate $\left(\mathrm{q}_{\mathrm{S}}\right)$ that was defined in $\mathrm{Eq}$. (2) since $q$ is defined in terms of $S_{S}$ as follows:

$$
q=\frac{D\left(S_{o}-S_{S}\right)}{X}
$$

by combining Eqs. (2), (8), (9) and (10), an equation that relates the measured substrate consumption specific rate with the specific microbial growth rate was obtained:

$$
q=\frac{\left(1-Y_{P / S}\right)}{Y_{X / S}} \mu
$$

and combining Eqs. (4) and (11) the following expression was obtained:

$$
q=\frac{\left(1-Y_{P / S}\right)}{Y_{X / S}} f_{M} D+\frac{\left(1-Y_{P / S}\right)}{Y_{X / S}} k d
$$

Considering a Monod type kinetics (Monod, 1949):

$$
\mu=\mu \max \frac{S}{K s+S}
$$

with:

$$
\begin{aligned}
\mathrm{m}_{\max }= & \text { maximum specific microbial growth rate, } \\
\mathrm{Ks}= & \text { saturation constant (substrate concentration } \\
& \text { corresponding to half of the maximum rate) }
\end{aligned}
$$

Taking into account Eqs. (8), (9), (10) and (13), the following expression was obtained:

$$
q=\left(1-Y_{P / S}\right) q_{S \max } \frac{S_{S}-Y_{P / S} S_{0}}{K S\left(1-Y_{P / S}\right)+S_{S}-Y_{P / S} S_{0}}
$$

where:

$$
\mathrm{q}_{\mathrm{Smax}}=\mathrm{m}_{\max } / \mathrm{Y}_{\mathrm{X} / \mathrm{S}}
$$

If all quantities were expressed in oxygen units, the oxidation coefficient (Irvine and Bryers, 1985) was calculated as:

$$
Y_{O / S}=1-Y_{X / S}-Y_{P / S}
$$

The maximum oxygen consumption specific rate $\left(\mathrm{q}_{\mathrm{O} 2 \max }\right)$ was calculated as:

$$
q_{O 2 \max }=Y_{O / S} q_{S \max }
$$

\section{Respirometric technique}

During the endogenous phase of respiration (characterised by the absence of oxidisable substrate) oxygen is utilised at a constant rate. When a pulse of substrate $(\mathrm{Sa})$ is injected into the respirometric cell, oxygen is consumed due to both substrate utilisation and endogenous respiration; an increase in OUR is observed. After a certain time the respiration rate returns to a value equal to, or slightly different from, the original endogenous phase rate (Fig. 1). Considering the specific endogenous rate of oxygen consumption

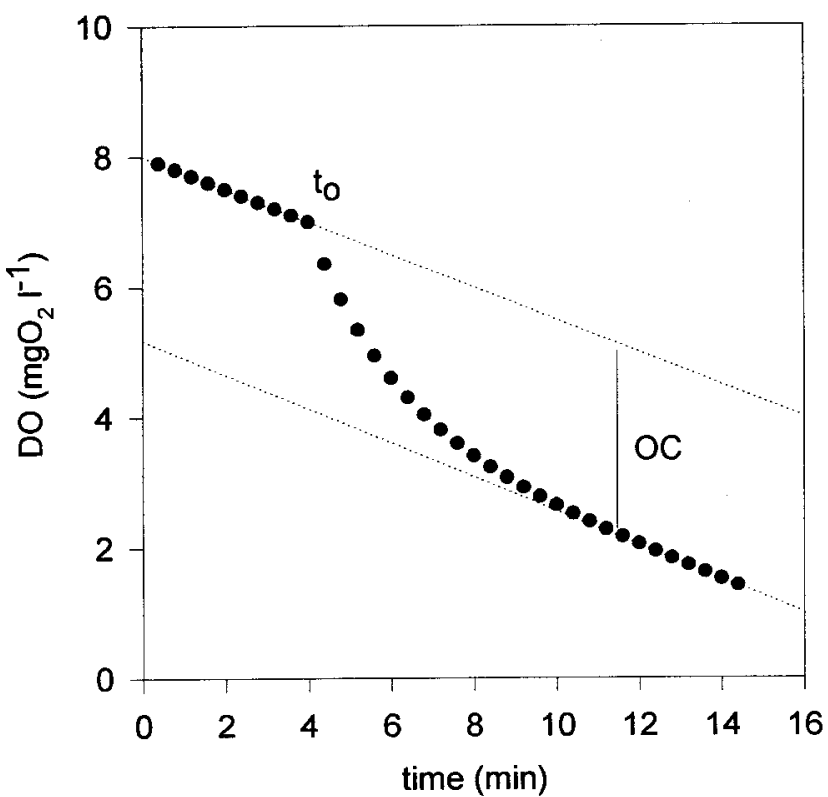

Figure 1

Recorder chart with a typical respirometric curve

$\left(\mathrm{q}_{\mathrm{Oe}}\right)$ and the specific oxygen consumption rate measured after a substrate pulse $\left(\mathrm{q}_{\mathrm{Ol}}\right)$, the specific oxygen consumption rate due exclusively to substrate utilisation $\left(\mathrm{q}_{\mathrm{O} 2}\right)$ was calculated, as follows:

$$
q_{O 2}=q_{O_{t}}-q_{O_{e}}=q_{O 2 \max } \frac{S a}{K s+S a}
$$

Sigmoidal curves of DO as a function of time (Fig. 1) can be expressed according to the following equations:

$$
\begin{array}{lrl}
D O^{<} & =a+r_{O e} t & t<t_{o} \\
D O^{>} & =D O^{<}+O C\left[\exp \left(-K\left(t-t_{0}\right)-1\right]\right. & t \geq t_{o}
\end{array}
$$

where:

a and $r_{\mathrm{O}}$ are the intercept and the slope of the straight line corresponding to oxygen consumption under endogenous respiration, that is, before substrate pulse addition;

$t_{0}$ is the time at which the substrate enters into the respirometer; and

OC is the oxygen utilised to consume the substrate added with the pulse.

From the derivative of Eq. (18) with respect to time $(\mathrm{t})$ at $\mathrm{t}=\mathrm{t}_{\mathrm{O}}$, the maximum oxygen consumption rate $\left(\mathrm{r}_{\mathrm{Ot}}\right)$ was obtained:

$$
r_{O t}=-O C \quad K+r_{O e}
$$

Eq. (19) was divided by the concentration of biomass in the respirometer $(\mathrm{Xr})$ leading to the following expression:

$$
q_{O t}=-\frac{O C K}{X_{r}}+q_{o e}
$$

where

$$
\begin{aligned}
& \mathrm{q}_{\mathrm{Ot}}=\mathrm{r}_{\mathrm{O}} / \mathrm{Xr} \\
& \mathrm{q}_{\mathrm{O} 2}=\mathrm{r}_{\mathrm{O} 2} / \mathrm{Xr} .
\end{aligned}
$$

The specific rate of oxygen consumption for the added substrate concentration $\left(\mathrm{q}_{\mathrm{O} 2}\right)$ can be obtained from Eq. (20) as OC K/ Xr. 


\begin{tabular}{|c|c|c|c|c|c|c|}
\hline \multicolumn{7}{|c|}{$\begin{array}{l}\text { TABLE } 1 \\
\text { Basic data obtained from the continuous-feed method and the respirometric } \\
\text { technique }\end{array}$} \\
\hline \multirow[t]{2}{*}{$D\left(h^{-1}\right)$} & \multicolumn{3}{|c|}{ Continuous-feed method } & \multicolumn{3}{|c|}{ Respirometric technique } \\
\hline & $\begin{array}{c}\text { Ss } \\
\left(\mathrm{mgCOD} \cdot \ell^{-1}\right)\end{array}$ & $\begin{array}{c}\mathbf{X} \\
\left(\mathbf{m g V S S} \cdot \ell^{-1}\right)\end{array}$ & $\begin{array}{c}\mathrm{DO} \\
\left(\mathrm{mgO}_{2} \cdot \ell^{-1}\right)\end{array}$ & $\begin{array}{c}\mathrm{q}_{\mathrm{O} \max } \\
\left(\mathrm{mgO}_{2}\right. \\
\left(\mathrm{mgVSS}^{-1} \cdot \mathrm{h}^{-1}\right)\end{array}$ & $\begin{array}{c}\mathrm{Ks} \\
\left(\mathrm{mgCOD} \cdot \ell^{-1}\right)\end{array}$ & $\begin{array}{c}\mathrm{Y}_{\mathrm{O} / \mathrm{s}} \\
\left(\mathrm{mgO}_{2}\right. \\
\left.\mathrm{mgCOD}^{-1}\right)\end{array}$ \\
\hline $\mathbf{0 . 0 1}$ & 99 & 460 & 8.4 & 0.054 & 2.0 & 0.24 \\
\hline $\mathbf{0 . 0 2}$ & 104 & 546 & - & - & - & - \\
\hline $\mathbf{0 . 0 3}$ & 103 & 552 & 8.0 & 0.052 & 5.7 & 0.27 \\
\hline 0.03 & 104 & 562 & 8.0 & 0.087 & 2.0 & 0.27 \\
\hline 0.06 & 118 & 896 & 4.8 & 0.088 & 3.7 & 0.27 \\
\hline 0.09 & 156 & 1148 & 1.0 & 0.085 & 9.3 & 0.27 \\
\hline 0.11 & 268 & 1025 & 0.5 & 0.114 & 4.2 & 0.22 \\
\hline 0.13 & 668 & 930 & 0.3 & 0.132 & 4.3 & 0.25 \\
\hline 0.14 & 424 & 1260 & 0.3 & 0.104 & 25.2 & 0.23 \\
\hline 0.15 & 854 & 1030 & 0.1 & 0.112 & 25.7 & 0.27 \\
\hline
\end{tabular}

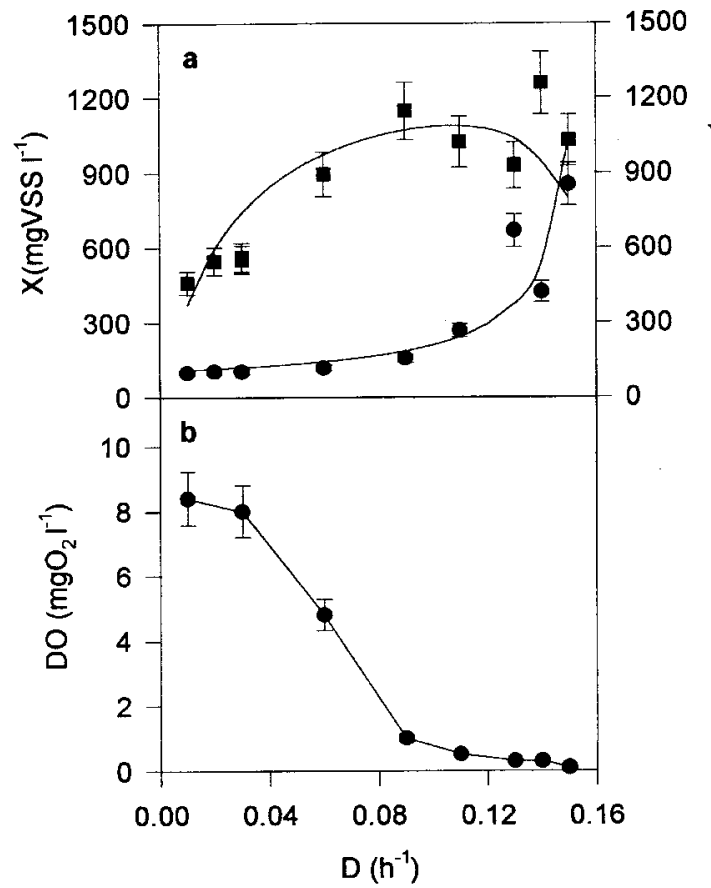

Figure 2

Effect of dilution rate $D$ on: a) biomass concentration $X(\mathbf{-})$ and soluble organic matter in the reactor $S s$ (॰) and b) dissolved oxygen $D O$.

Solid lines correspond to the developed model.

The oxidation coefficient $\left(\mathrm{Y}_{\mathrm{O} / \mathrm{S}}\right)$ was calculated as the required amount of oxygen (OC) to consume the added substrate (Sa):

$$
Y_{O / S}=\frac{O C}{S a}=\frac{q_{O 2}}{q_{S}}=\frac{q_{O 2 \max }}{q_{S \max }}
$$

\section{Materials and methods}

\section{Wastewater}

A model system corresponding to the wastewater of a potatoprocessing plant was used. The stock wastewater was obtained dipping $1 \mathrm{~cm}^{3}$ cubes of potato in water at room temperature for $48 \mathrm{~h}$ (Bertola et al., 1999) and diluted to obtain $2000 \mathrm{mg} \mathrm{COD} \ell^{-1}$.

\section{Measurement techniques}

DO was measured with an electrode YSI model 58 (YSI Inc., Ohio, USA) with a polarographic membrane YSI 5775. COD and phosphorus determinations were performed by spectrophotometric techniques (COD Reactor Model 45600 and Spectrophotometer DR/2000, Hach Cop., Loveland, USA). Nitrogen was determined by Kjeldahl with a Büchi digestor (Büchi Laboratoriums-Technik, Flawil, Switzerland). Biomass concentration was expressed as VSS (Metcalf and Eddy, 1977). Microscopic observations of the microbial flora in the reactor were carried out by phase contrast using a Leitz Ortholux II microscope (Wetzlar, Germany).

\section{Biological reactors}

Two reactors of volume (V) $4.8 \ell$ were fed with dosing pumps. Air was supplied by aerators that also assisted in agitating the reactor. Ten experiments were carried out under continuous flow $(\mathrm{Q})$ using dilution rates $(\mathrm{D}=\mathrm{Q} / \mathrm{V})$ ranging between 0.01 and $0.15 \mathrm{~h}^{-1}$. Once steady state had been reached, microscope observations of the activated sludge were performed and the following parameters were determined in the mixed liquor: DO, biomass concentration as VSS, and organic matter content as soluble COD.

\section{Respirometric technique}

Respirometric measurements were assessed on an open respirometer; the respirometric cell is described in detail elsewhere (Chudoba et al., 1985; Drtil et al., 1993; Roš, 1993).

Activated sludges were obtained from the biological reactors operated at different dilution rates under steady state conditions. 
A culture volume of $400 \mathrm{~m} \ell$ was removed from the continuous reactor and was placed in the respirometric cell in absence of substrate. A nitrification inhibitor (Hach formulation 2533) was also added. The system was then aerated until a constant OUR was found, which corresponded to the endogenous respiration phase. Respirometric tests were carried out by adding different substrate amounts (wastewater of approximately $10000 \operatorname{mgCOD} \cdot \ell^{-1}$ ), that led to substrate concentrations (Sa) of between 1 and 100 $\operatorname{mgCOD} \cdot \ell^{-1}$ in the respirometer. Biomass concentration was considered constant since added substrate pulses $(0.1$ to $5 \mathrm{~m} \ell)$ corresponded to less than $5 \%$ culture volume change.

\section{Results and discussion}

\section{Wastewater characterisation}

The model wastewater system of the potato processing plant was standardised at $2000 \mathrm{mgCOD} \cdot \ell^{-1}$ for all experiments. Nitrogen and phosphorus content were 150 and $21 \mathrm{mg} \cdot \ell^{-1}$, respectively and the COD/N/P ratio was 100/7.5/1.1; this ratio is commonly accepted as being necessary for biomass growth (Winkler, 1996). These results are in accordance with a previous paper (Contreras et al., $2000 \mathrm{~b}$ ). Wijbenga et al. (1984) reported a COD/N/P ratio of 100/8.8/0.9 and 100/8.1/1.4 for deproteinised and protein-containing wastewater from the potato starch industry respectively.

\section{Continuous feed method}

Soluble organic matter content as $\operatorname{COD}\left(\mathrm{S}_{\mathrm{S}}\right)$, biomass as VSS $(\mathrm{X})$ and DO were measured in the continuously-stirred reactor as a function of D. Each run was carried out at different dilution rates. Ss and $X$ were measured until obtained values differed by less than $10 \%$ to ensure a steady state (Table 1 ). Average values were plotted and are shown in Figs. 2a, b; it can be observed that when D increased, DO decreased while Ss and X increased.

Microbial kinetic parameters were determined from the obtained results in a continuously-stirred tank reactor (see Appendix I). Using the value $S_{0}=2000 \operatorname{mgCOD} \cdot \ell^{-1}$, data of soluble organic matter content as COD (Ss) and volatile suspended solids $(\mathrm{X})$, obtained from the continuous operation of the aerobic reactor (Fig. 2a), the measured substrate consumption specific rate (q) was calculated for different dilution rates applying Eq. (10); the Eq. (14) was fitted to $q$ vs $S_{S}$ data and the following parameters were estimated by non-linear regression analysis: $\mathrm{q}_{\mathrm{S} \max }=0.19 \mathrm{mgCOD}$ $(\mathrm{mgVSS})^{-1} \cdot \mathrm{h}^{-1}, \mathrm{Ks}=8.3 \mathrm{mgCOD} \cdot \ell^{-1}$ and product yield $\mathrm{Y}_{\mathrm{P} / \mathrm{S}}=0.05$ $\operatorname{mgCOD}(\mathrm{mgCOD})^{-1}\left(\mathrm{R}^{2}=0.930\right)$. The goodness of fit is shown in Fig. 3 where experimental data of q were plotted as a function of $S_{S}$ and the curve corresponds to Eq. (14).

Considering the calculated value $\mathrm{Y}_{\mathrm{P} / \mathrm{S}}=0.05 \mathrm{mgCOD}(\mathrm{mgCOD})^{-1}$ and the inlet concentration $\mathrm{So}=2000 \mathrm{mgCOD} \cdot \ell^{-1}$, Eq.(7) yields a residual $\mathrm{COD}$ due to microbial product concentration $\mathrm{P}=100$ $\operatorname{mgCOD} \cdot \ell^{-1}$ for a totally degraded substrate $(S=0)$; thus, a concentration of $100 \mathrm{mgCOD} \cdot \ell^{-1}$ was the minimum value reached in the reactor (Fig. 3).

Parameters kd and $\mathrm{Y}_{\mathrm{X} / \mathrm{S}}$ were obtained from Eq. (12); a linear regression of $q$ vs. $D$ data, allowed determination of $\mathrm{Y}_{\mathrm{X} / \mathrm{S}}=0.61$ $\operatorname{mgVSS}(\mathrm{mgCOD})^{-1}$ and $\mathrm{kd}=0.04 \mathrm{~h}^{-1}$ with $\mathrm{R}^{2}=0.863$. By combining the obtained values of $\mathrm{Y}_{\mathrm{X} / \mathrm{S}}$ and $\mathrm{q}_{\mathrm{Smax}}$, a value of $\mathrm{m}_{\max }=0.12 \mathrm{~h}^{-1}$ was estimated (Eq. 9).

The adopted factor to convert the activated sludge biomass from VSS to oxygen units was $1.29 \mathrm{mgCOD}(\mathrm{mgVSS})^{-1}$ (Contreras et al., 2000 a). This value was used to determine $\mathrm{Y}_{\mathrm{x} / \mathrm{s}}=0.79$ $\mathrm{mgCOD}(\mathrm{mgCOD})^{-1}$ (expressed in oxygen units). Eqs. (15) and

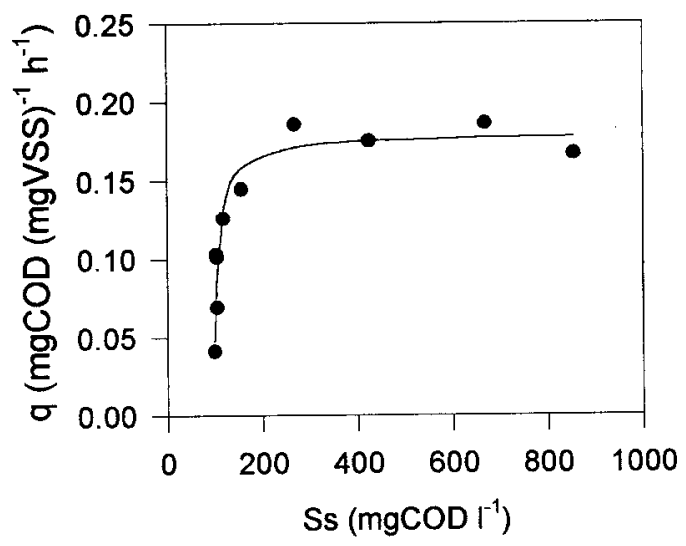

Figure 3

Measured substrate consumption specific rate $(q)$ as a function of organic matter concentration in the reactor (Ss). (•) Experimental values. (-) Eq. (15)

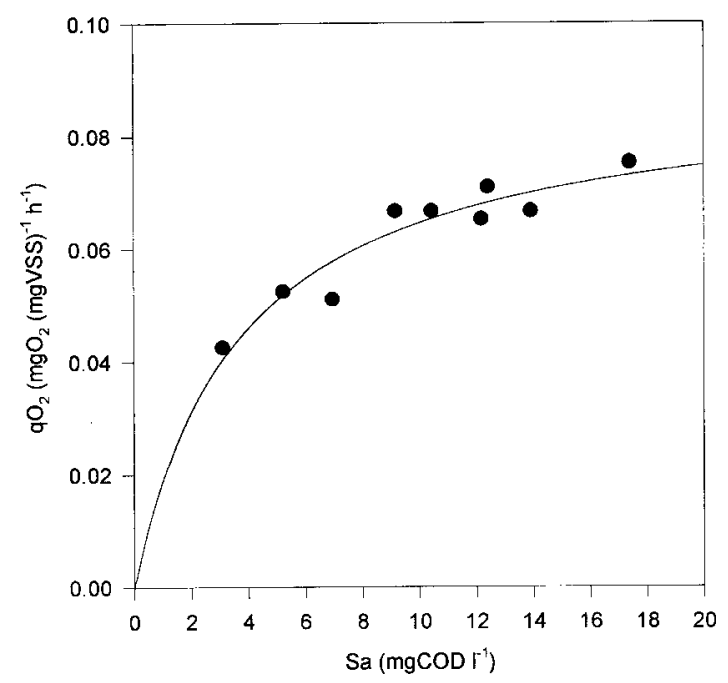

Figure 4

A typical relationship between $q_{\mathrm{O}_{2}}$ and $\mathrm{Sa}$. (•) Experimental values. (-) Eq. (17): $q_{\text {O2max }}=0.088 \mathrm{mgO}_{2}\left(\mathrm{mgVSS}^{-1} \mathrm{~h}^{-1} ; \mathrm{Ks}=3.7\right.$ $m g C O D \ell^{-1} ;$ in this case $D=0.06 \mathrm{~h}^{-1}$.

(16) allow calculation of $\mathrm{Y}_{\mathrm{O} / \mathrm{s}}=0.16 \mathrm{mgO}_{2}(\mathrm{mgCOD})^{-1}$ and $\mathrm{q}_{\mathrm{O} 2 \max }$ $=0.03 \mathrm{mgCOD}(\mathrm{mgVSS})^{-1} \mathrm{~h}^{-1}$ respectively. Table 2 shows the obtained parameters using the continuous-feed method.

\section{Respirometric technique}

A respirometric technique was also applied to assess the kinetic parameters on the sludges obtained from the continuously-stirred reactor operating at different $D$ values (see Appendix II). Parameters $\mathrm{q}_{\mathrm{O} 2 \max }$ and Ks from Eq. (17) were calculated by measuring $\mathrm{q}_{\mathrm{O} 2}$ at different added substrate concentrations ( $\mathrm{Sa}$ ); an example is shown in Fig. 4. The values of $q_{\mathrm{O} 2 \max }$ and Ks obtained at different $D$ values are shown in Table 1. Values of $\mathrm{q}_{\mathrm{O} 2 \max }$ and Ks increased with $\mathrm{D}$; $\mathrm{q}_{\mathrm{O} 2 \max }$ ranged between 0.05 and $0.13 \mathrm{mgO}_{2}(\mathrm{mgVSS})^{-1} \cdot \mathrm{h}^{-1}$ and $\mathrm{Ks}$ between 2 and $26 \operatorname{mgCOD} \cdot \ell^{-1}$ for D values varying between 0.01 and $0.15 \mathrm{~h}^{-1}$ (Fig. 5a, b). For all the experiments, the mean value of $\mathrm{Y}_{\mathrm{O} / \mathrm{S}}$ was $0.25 \mathrm{mgO}_{2}(\mathrm{mgCOD})^{-1} ; \mathrm{q}_{\mathrm{Smax}}$ was calculated for each D value using Eq. (16); and the Ks values ranged between 0.20 and $0.52 \mathrm{mgCOD}(\mathrm{mgVSS})^{-1} \cdot \mathrm{h}^{-1}$. Table 2 shows the obtained parameters using the respirometric technique. 


\begin{tabular}{|c|c|c|}
\hline \multicolumn{3}{|c|}{$\begin{array}{l}\text { TABLE } 2 \\
\text { A comparison between the estimated parameters } \\
\text { using the continuous-feed method and the } \\
\text { respirometric technique }\end{array}$} \\
\hline & $\begin{array}{l}\text { Continuous- } \\
\text { feed method }\end{array}$ & $\begin{array}{c}\text { Respirometric } \\
\text { technique }\end{array}$ \\
\hline$q_{\text {smax }}\left(\operatorname{mgCOD}(\mathbf{m g V S S})^{-1} \cdot \mathbf{h}^{-1}\right)$ & $0.19(0.01)$ & $0.20-0.52$ \\
\hline $\operatorname{Ks~}\left(\operatorname{mgCOD} \cdot \ell^{-1}\right)$ & $8.4(3.2)$ & $2.0-26.0$ \\
\hline$Y_{\mathrm{P} / \mathrm{S}}\left(\mathrm{mgCOD}(\mathrm{mgCOD})^{-1}\right)$ & $0.05(0.001)$ & -- \\
\hline$Y_{x / s}\left(m g V S S(m g C O D)^{-1}\right)$ & $0.61(0.09)$ & -- \\
\hline $\mathbf{k d}\left(h^{-1}\right)$ & $0.04(0.01)$ & -- \\
\hline$m_{\max }\left(h^{-1}\right)$ & $0.12(0.02)$ & -- \\
\hline$Y_{\mathrm{x} / \mathrm{S}}\left(\operatorname{mgCOD}(\mathrm{mgCOD})^{-1}\right)$ & $0.79(0.11)$ & -- \\
\hline $\mathrm{Y}_{\mathrm{O} / \mathrm{S}}\left(\mathrm{mgO}_{2}(\mathrm{mgCOD})^{-1}\right)$ & $0.16(0.11)$ & $0.25(0.02)$ \\
\hline $\mathbf{q}_{\mathrm{O} 2 \max }\left(\mathrm{mgO}_{2}(\mathrm{mgVSS})^{-1} \cdot \mathbf{h}^{-1}\right)$ & $0.03(0.02)$ & $0.05-0.13$ \\
\hline
\end{tabular}

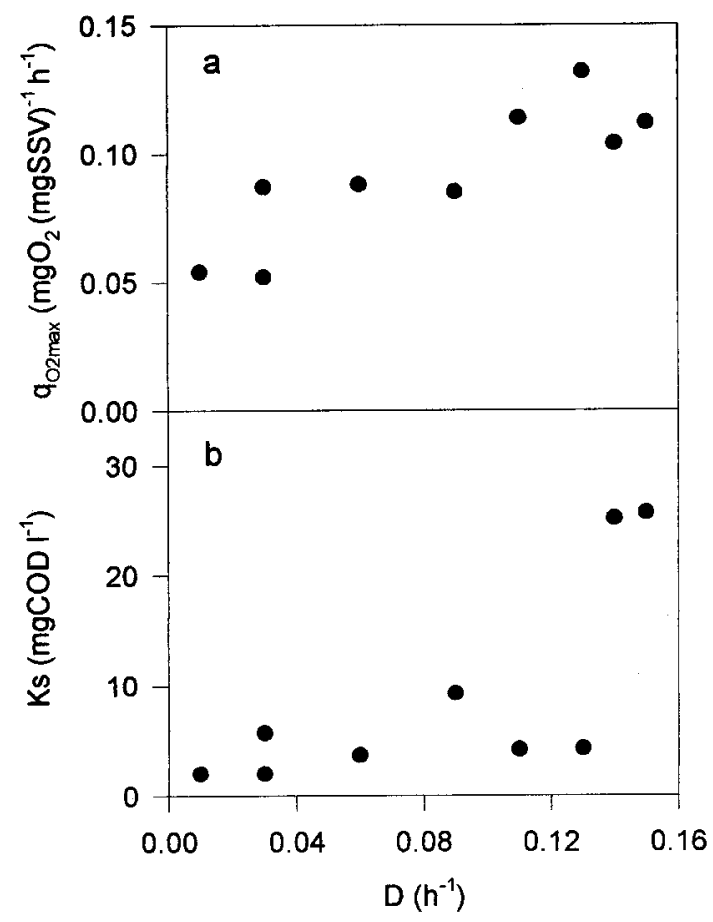

Figure 5

Kinetic parameters obtained by the respirometric method as a function of the dilution rate $(D)$ at which sludges were obtained. (a) maximum oxygen consumption specific rate $\left(q_{\text {O2max }}\right)$ (b) saturation constant (Ks)

\section{Comparison between both applied methods}

Obtained values of $\mathrm{Ks}$ and $\mathrm{Y}_{\mathrm{O} / \mathrm{S}}$ using both methods reflected no significant differences; however, values of $\mathrm{q}_{\mathrm{Smax}}$ and $\mathrm{q}_{\mathrm{O} 2 \max }$ using the continuous feed method were lower than those determined by the respirometric technique (Table 2).

The use of respirometric data to assess kinetic parameters is based on an energy balance (Dang et al., 1989): electrons involved in substrate oxidation should be transferred either to the terminal
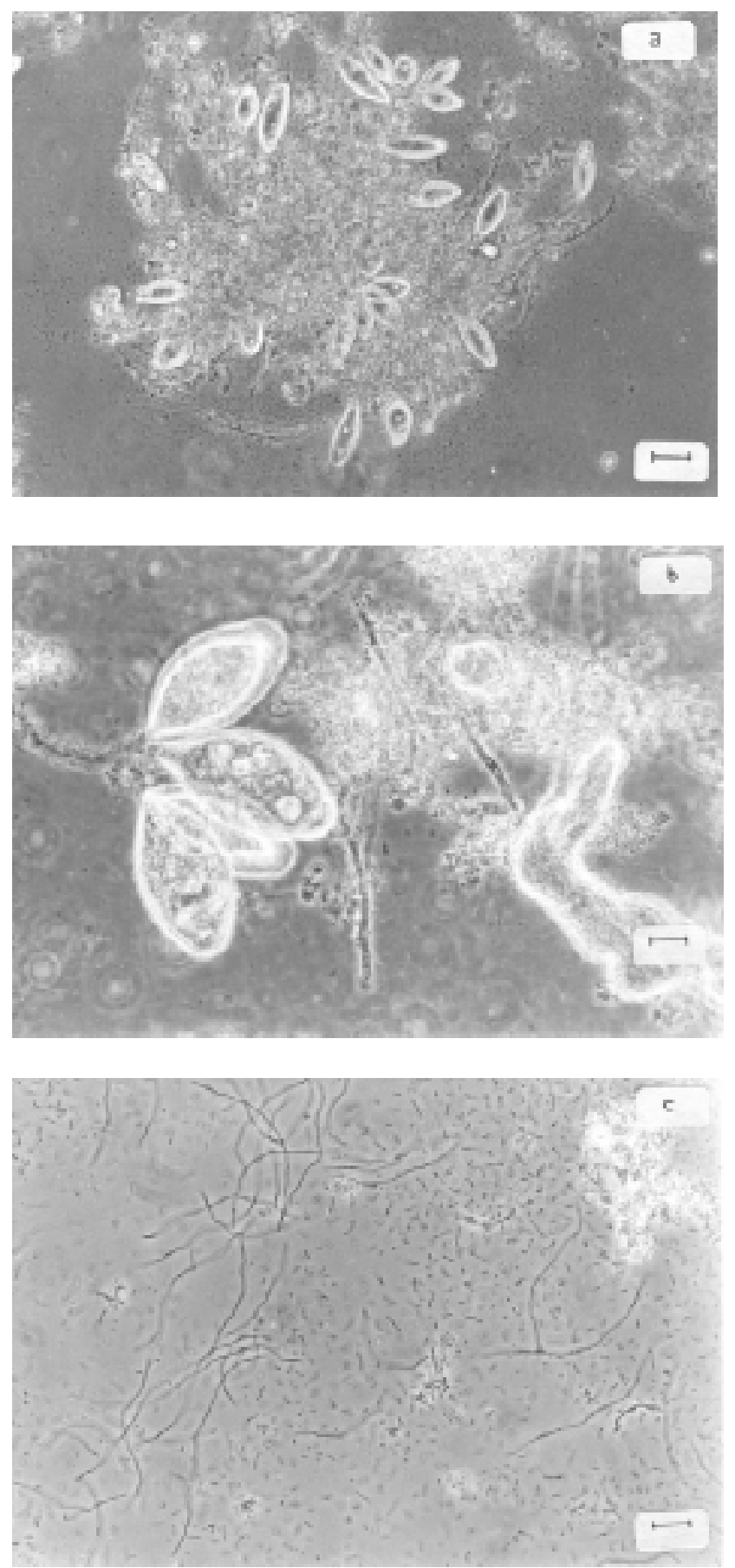

Figure 6

Micrographs of sludge samples obtained with different dilution rates $(D)$

(a) $D=0.03 h^{-1}(125 X$, Bar $50 \mathrm{~mm})$

(b) $D=0.09 h^{-1}(300 X$, Bar $30 \mathrm{~mm})$

(c) $D=0.15 h^{-1}(300 X$, Bar $30 \mathrm{~mm})$

acceptor of electrons (oxygen in aerobic systems) or incorporated into new biomass or into microbial products. Considering that the consumed oxygen is used for the oxidation of the substrate; the formation of biomass; and microbial products, the sum of the yields $\left(\mathrm{Y}_{\mathrm{O} / \mathrm{S}}, \mathrm{Y}_{\mathrm{P} / \mathrm{S}}\right.$ and $\mathrm{Y}_{\mathrm{X} / \mathrm{S}}$ ) expressed in oxygen units must be 1 (Irvine and Bryers, 1985). In this work, the sum of the experimentally obtained yields using the different techniques was very close to $1\left(\mathrm{Y}_{\mathrm{O} / \mathrm{S}}+\mathrm{Y}_{\mathrm{P} / \mathrm{S}}\right.$ 
$\left.+\mathrm{Y}_{\mathrm{X} / \mathrm{S}}=0.25+0.05+0.79=1.09\right) ;$ this result indicates that stoichiometric parameters $\left(\mathrm{Y}_{\mathrm{O} / \mathrm{S}}, \mathrm{Y}_{\mathrm{P} / \mathrm{S}}\right.$ and $\left.\mathrm{Y}_{\mathrm{X} / \mathrm{S}}\right)$ can be accurately estimated by both methods.

\section{Microscope observations}

Changes in microbial composition in the continuous reactor was determined by microscope observation. For $\mathrm{D}<0.10 \mathrm{~h}^{-1}$, sludge contained mainly floc-forming bacteria, a low number of filamentous micro-organisms and abundant protozoa (Fig. 6a, b). As D increased, protozoa almost disappeared and filamentous micro-organisms increased (Fig. 6c). Filamentous sludges, which appeared at high D values and low DO concentration, showed a higher $\mathrm{q}_{\mathrm{O} 2 \max }$ and higher Ks values than sludges produced by floc-forming bacteria (Fig. 6a, b).

The observed changes of microbial flora could be associated with the decrease in DO content and/or the increase in organic loading. Taguchi et al. (1978) also observed the filamentous bulking phenomenon with increasing dilution rates. These authors studied two strains of Flavobacterium; one was a floc-forming and the other a filamentous strain reporting an increase of filamentous micro-organisms as D increased. Besides, Tanaka and coworkers (1985) studied mixed cultures of floc-forming bacteria (Pseudomonas sp.) and filamentous bacteria (Sphaerotilus sp.); they observed that when DO was above $1 \mathrm{mg} \cdot \ell^{-1}$ floc formation and settling properties were good; besides, when DO was below 0.8 $\mathrm{mg} \cdot \ell^{-1}$ filamentous bacteria were the predominant micro-organisms.

These results show the relevance of the previous history of the culture to determine kinetic parameters by the respirometric method. The low substrate/biomass ratios used in the respirometric method limit multiplication and growth of micro-organisms maintaining the initial physiological state of the original biomass (Grady et al., 1996). Consequently, the observed differences in the respirometric parameters reflect the physiological state and/or the microbial composition.

\section{Conclusions}

Data from continuous-feed experiments allowed the calculation of kinetic parameters using a Monod type equation and mass balances of substrate, biomass and microbial product. In addition, the respirometric technique allowed also for the calculation of kinetic parameters. However, these parameters depended on D and/or on DO.

Non-significant differences between $\mathrm{Ks}$ and $\mathrm{Y}_{\mathrm{O} / \mathrm{S}}$ determined by both applied methods were observed.

Microscope observations showed that sludge composition was a function of dilution rate. Low D values (low Ss and high DO concentrations) yielded sludges mainly formed by floc-forming bacteria. On the contrary, high D values (high Ss and low DO concentrations) yielded sludges mainly formed by filamentous micro-organisms. Since the low substrate/biomass ratios used in the respirometric method limit multiplication and growth of microorganisms maintaining the initial physiological state of the original biomass, the observed differences in the respirometric parameters reflected the actual microbial composition.

\section{Acknowledgements}

Authors gratefully acknowledge the financial support to this project provided by Project 358 BID 802/OC-AR Agencia Nacional de Promoción Científica y Tecnológica, Consejo Nacional de Investigaciones Científicas y Técnicas (CONICET) and Facultad de Ingeniería, Universidad Nacional de la Plata, Argentina.

\section{References}

AICHINGER G, GRADY CPL Jr AND TABAK HH (1992) Application of respirometric biodegradability testing protocol to slightly soluble organic compounds. Water Environ. Res. 64 890-900.

BECCARI M, MAJONE M, MASSANISSO P and RAMADORI R (1998) A bulking sludge with high storage response selected under intermittent feeding. Water Res. 32 3403-3413.

BERTOLA N, PALLADINO L, BEVILACQUA A and ZARITZKY N (1999) Optimisation of the design parameters in an activated sludge system for the wastewater treatment of a potato processing plant. J. Food Eng. 40 27-33.

CASEY TG, WENTZEL MC and EKAMA GA (1999) Filamentous organism bulking in nutrient removal activated sludge systems. Paper 11: A biochemical/microbiological model for proliferation of anoxicaerobic (AA) filamentous organisms. Water SA 25 443-451.

CECH JS, CHUDOBA J and GRAU P (1984) Determination of kinetic constants of activated sludge microorganisms. Water Sci. Technol. 17 259-272.

CHUDOBA J, CECH JS, FARKAC J and GRAU P (1985) Control of activated sludge filamentous bulking. Experimental verification of a kinetic selection theory. Water Res. 19 191-196.

CHUDOBA P, CAPDEVILLE B and CHUDOBA J (1992) Explanation of biological meaning of the So/Xo ratio in batch cultivation. Water Sci. Technol. 26 743-751.

CONTRERAS EM, BERTOLA NC, GIANNUZZI L and ZARITZKY NE (2000a) Un método alternativo para la determinación de biomasa en cultivos puros y sistemas de barros activados. XI Congreso Argentino de Saneamiento y Medio Ambiente. AIDIS Argentina. In CD.

CONTRERAS EM, GIANNUZZI L and ZARITZKY N (2000b) Growth kinetics of the filamentous microorganism Sphaerotilus natans in a model system of a food industry wastewater. Water Res. 34 4455-4463.

DANG JS, HARVEY DM, JOBBAGY A and GRADY CPL (Jr.) (1989) Evaluation of biodegradation kinetics with respirometric data. J. Water Pollut. Control Fed. 61 1711-1721.

DIRCKS K, PIND PF MOSBAEK H and HENZE M (1999) Yield determination by respirometry - The possible influence of storage under aerobic conditions in activated sludge. Water SA 25 69-74.

DRTIL M, NÉMETH P and BODÍK I (1993) Kinetic constants of nitrification. Water Res. 27 35-39.

ELLIS TG, BARBEAU DS, SMETS BF and GRADY CPL (Jr.) (1996) Respirometric technique for determination of extant kinetic parameters describing biodegradation. Water Environ. Res. 68 917-926.

GRADY CPL (Jr.), SMETS BF and BARBEAU DS (1996) Variability in kinetic parameter estimates: a review of possible causes and a proposed terminology. Water Res. 30 742-748.

HOLMBERG U, OLSSON G and ANDERSSON B (1989) Simultaneous DO control and respiration estimation. Water Sci. Technol. 21 11851195.

IRVINE RL and BRYERS JD (1985) Stoichiometry and kinetics of waste treatment. In: Robinson CW and Howell JA (eds.) Comprehensive Biotechnology Vol. 4. Pergamon, New York. 757-772.

KING EF and DUTKA BJ (1986) Respirometric techniques. In: Dutka B and Bitton G (eds.) Toxicity Testing Using Microorganisms Vol. 1, CRC Press, Fla. 75-112.

KÖHNEM(1985) Practical experiences with a new on-line BOD measuring device. Environ. Technol. Lett. 6 546-555.

KONG Z, VANROLLEGHEM P, WILLEMS P and VERSTRAETE W (1996) Simultaneous determination of inhibition kinetics of carbon oxidation and nitrification with a respirometer. Water Res. 30 825-836.

LIU PH, SVORONOS SA and KOOPMAN B (1998) Experimental and modelling study of diauxic lag of Pseudomonas denitrificans switching from oxic to anoxic conditions. Biotech. Bioeng. 60 649-655.

MAJONE M, DIRCKS K and BEUN JJ (1999) Aerobic storage under dynamic conditions in activated sludge processes. The state of the art. Water Sci. Technol. 39 61-73.

METCALF and EDDY (1977) Tratamiento y Depuración de las Aguas Residuales. Labor SA (ed.) Barcelona, Spain.

MONOD J (1949) The growth of bacterial cultures. Ann. Rev. Microbiol. 3 371-394. 
MUSVOTO EV, LAKAY MT, CASEY TG, WENTZEL MC and EKAMA GA (1999) Filamentous organism bulking in nutrient removal activated sludge systems. Paper 8: The effect of nitrate and nitrite. Water SA 25 397-407.

ORHON D, YILDIZ G, UBAY COKGOR E and SOZEN S (1995) Respirometric evaluation of the biodegradability of confectionery wastewaters. Water Sci. Technol. 32 11-19.

PAILTHORP RE, FILBERT JW and RICHTER GA (1975) Waste Disposal. In: Talburt WF and Smith O (eds.) Potato Processing. Wesport: AVI, 646-691.

PIRT SJ (1975) Principles of Microbe and Cell Cultivation. Blackwell Scientific Publications, New York.

ROŠ M (1993) Respirometry of Activated Sludge. Technomic, U.S.A.

SEZGIN M, JENKINS D and PARKER DS (1978) A unified theory of filamentous activated sludge bulking. J. Water Pollut. Control Fed. 50 362-381.

SOLLFRANK U and GUJER W (1990) Simultaneous determination of oxygen uptake rate and oxygen transfer coefficient in activated sludge systems by an on-line methods. Water Res. 24 725-732.

TAGUCHI H, YOSHIDA T and NAKATANI K (1978) Studies on a model mixed culture for simulation of a bulking phenomenon. J. Ferment. Technol. 50 158-168.

TANAKA H, KURANO N, UEDA S, UEDA S, OKAZAKI M and MIURA Y (1985) Model system of bulking and flocculation in mixed culture of Sphaerotilus sp. and Pseudomonas sp. for dissolved oxygen deficiency and high loading. Water Res. 19 563-571.

UBISI MF, JOOD TW, WENTZEL MC and EKAMA GA (1997) Activated sludge mixed liquor heterotrophic active biomass. Water SA 23 239-248.

VANROLLEGHEM PA, KONG Z, ROMBOUTS G and VERSTRAETE W (1994) An on-line respirographic biosensor for the characterisation of load and toxicity of wastewaters. J. Chem. Tech. Biotechnol. 59 321-333.

WANNER J (1994) Activated Sludge Bulking and Foaming Control. Technomic Publishing Co., Inc. Lancaster, USA.

WIJBENGA DJ, MEIBREG JBM and BRUNT K (1984) Wastewater purification in the potato starch industry. In: Houwink EH and Van der Meer RR (eds.) Innovations in Biotechnology. Elsevier Science Publishers B.V., Amsterdam. 121-132.

WILLIAMSON KJ and McCARTY PL (1975) Rapid measurement of Monod half-velocity coefficients for bacterial kinetics. Biotech. Bioeng. 14 915-924.

WINKLER MA (1996) Tratamiento Biológico de Aguas de Desecho. Limusa SA (eds.) Mexico D.F.

\section{Appendix I}

Diagram showing the calculations to determine the kinetics and stoichiometric parameters in the continuous feed system (classical technique)

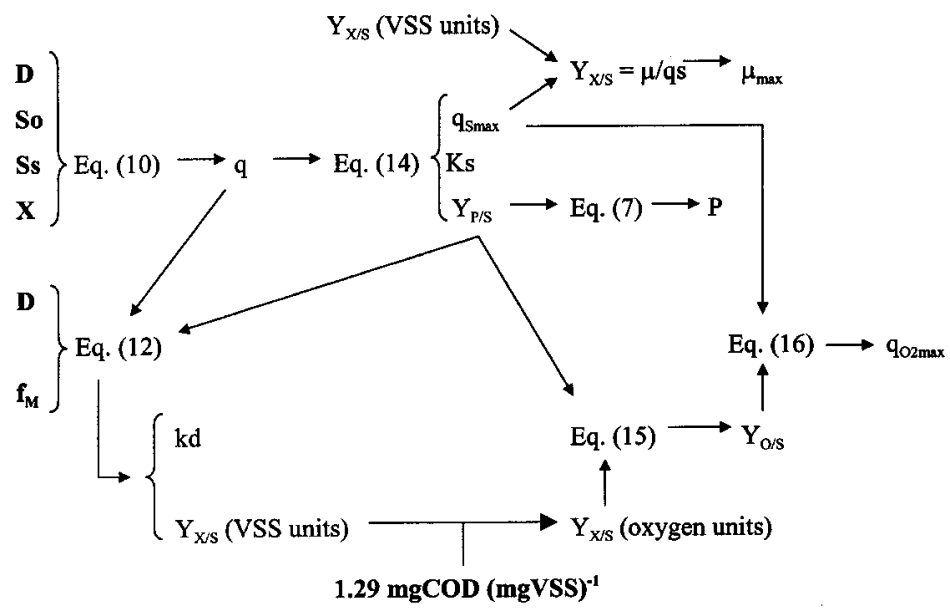

Basic data: $\mathrm{D}, \mathrm{S}_{0}, \mathrm{Ss}, \mathrm{X}, \mathrm{f}_{\mathrm{M}}$

\section{Appendix II}

Diagram showing the calculations to determine the parameters using the respirometric technique.

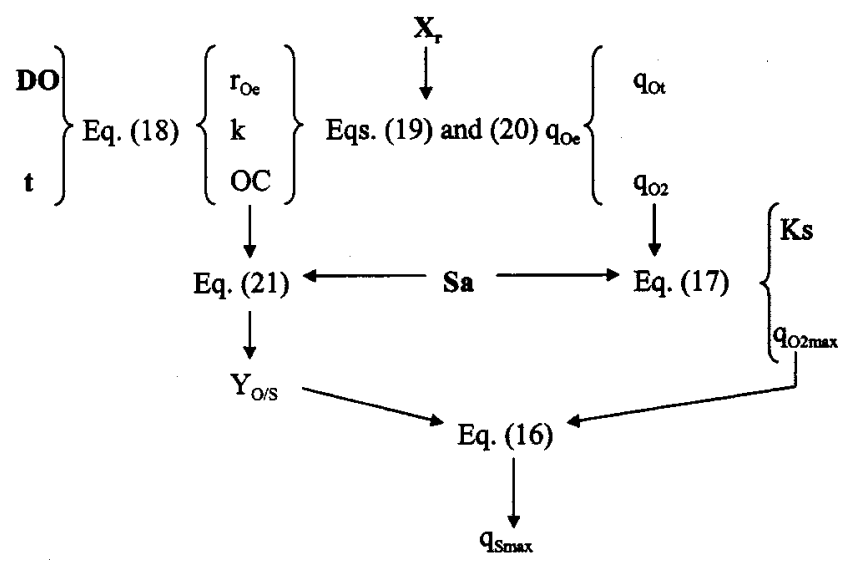

Basic data: DO, $\mathrm{t}, \mathrm{X}_{\mathrm{r}}, \mathrm{Sa}$ 